\title{
METRONIDAZOLE RESISTANCE IN ANAEROBES ISOLATED FROM CHRONIC PERIODONTITIS CASES
}

\author{
Sushma Narayan Pednekar1, Sae Satish Pol'2, Sangeeta Andhare Agrawal', Renu Satish Bharadwaj ${ }^{4}$
}

${ }^{1}$ Assistant Professor, Department of Microbiology, B. J. Government Medical College, Pune.

${ }^{2}$ Associate Professor, Department of Microbiology, B. J. Government Medical College, Pune.

3 Professor, Department of Dentistry, B. J. Government Medical College, Pune.

${ }^{4}$ Professor \& HOD, Department of Microbiology, B. J. Government Medical College, Pune.

\section{ABSTRACT}

Periodontitis is the most frequent oral health problem in the world. The infection is primarily caused by anaerobic microorganisms. Metronidazole is the most commonly used drug to treat the infection but recently the anaerobes have shown the resistance to this drug. Therefore, the present study was undertaken to isolate and identify the anaerobes associated with periodontitis and study their susceptibility pattern to the Metronidazole. Total 90 samples were collected from chronic perio dontitis cases. Anaerobes were isolated in $71 \%$ of periodontitis cases. Gram positive organisms were more predominantly isolated than Gram negative organisms. The Gram negative anaerobes were found to be $100 \%$ sensitive to Metronidazole while Gram positive anaerobe s showed $8 \%$ resistance to Metronidazole.

\section{KEYWORDS}

Anaerobes, Chronic periodontitis, Metronidazole.

HOW TO CITE THIS ARTICLE: Pednekar SN, Pol SS, Agrawal SA, et al. Metronidazole resistance in anaerobes isolated from chronic periodontitis cases. J Evolution Med Dent Sci 2016;5(4):270-271, DOI: 10.14260/jemds/2016/57

\section{INTRODUCTION}

Chronic periodontitis is the major cause of tooth loss in adults.[1] It is multifactorial in etiology. Bacteria play an important role in pathogenesis. Anaerobic bacteria are predominantly implicated in their pathogenesis. [2] Detection of anaerobic bacteria along with their susceptibility pattern is important for better management of any anaerobic infections. However, most laboratories do not attempt to isolate or do the susceptibility testing of anaerobes as it is very tedious, costly and time consuming. The commonly used antimicrobial for anaerobic infection is Metronidazole. However, anaerobes are now developing resistance to this Nitroimidazoles also. The present study was undertaken to identify the role of anaerobes in chronic periodontitis patients with their antimicrobial susceptibility pattern to Metronidazole.

Samples were collected from 90 patients showing clinical and radiological evidence of chronic periodontitis with the assistance of the treating dentists. A total 25 samples were collected from subjects without clinical signs of periodontal disease as a control group. The samples were processed for isolation and identification of anaerobic bacteria as per standard microbiological techniques. The antimicrobial susceptibility of anaerobes for Metronidazole was done by using E test (Biomerieux) method as per CLSI guidelines. Anaerobes were isolated in $71 \%$ of periodontitis cases and $24 \%$ of healthy subjects. Gram positive organisms were more predominantly isolated than Gram negative from periodontitis patients (Table 1). Van Winkelhoff et al.[3] has reported Peptococcus micros (94\%), Prevotella SPP (87.9\%) and Porphyromonas SPP (59\%) while Salari et al.[4] has found Peptococcus micros (1.3\%), Porphyromonas SPP (21.9\%) and Prevotella SPP (10.5\%) as the predominant anaerobes.

Financial or Other, Competing Interest: None.

Submission 15-06-2015, Peer Review 16-06-2015,

Acceptance 09-01-2016, Published 14-01-2016.

Corresponding Author:

Dr. Sushma N. Pednekar,

Department of Microbiology,

$1^{\text {st }}$ Floor, B. J. Govt. Medical College,

Pune-411001.

E-mail: contactsushma@gmail.com

DOI:10.14260/jemds/2016/57
These variations could be attributed to geographical differences. Anaerobes were more frequently isolated from periodontitis patients than control group showing their association with periodontitis (Table 1). The Gram negative anaerobes were found to be $100 \%$ sensitive to Metronidazole while Gram positive anaerobes showed 8\% resistance to Metronidazole. Catherine et al. have reported $48.2 \%$ resistance to Metronidazole in anaerobes isolated from foot ulcers.[5]

Not much data is available on Metronidazole resistance in anaerobes isolated from chronic periodontitis cases. Resistance to Metronidazole observed in the present study is alarming and highlights the need of isolating anaerobes from periodontal pockets and studying their antimicrobial susceptibility pattern for better management of patients with chronic periodontitis.

\begin{tabular}{|c|c|c|}
\hline $\begin{array}{l}\text { Anaerobes } \\
\text { Isolated }\end{array}$ & $\begin{array}{c}\text { Periodontitis } \\
\text { Patients N } \\
(\%) \\
\end{array}$ & $\begin{array}{c}\text { Healthy } \\
\text { Subjects N (\%) }\end{array}$ \\
\hline $\begin{array}{l}\text { Gram Positive Organisms } \\
\text { Peptostreptococcus } \\
\text { Products } \\
\text { Peptostreptococcus Micros } \\
\text { Peptostreptococcus } \\
\text { Anaerobius } \\
\text { Peptostreptococcus } \\
\text { Magnus } \\
\text { Eubacterium Spp. }\end{array}$ & $\begin{array}{l}12(13.3) \\
10(11.1) \\
10(11.1) \\
6(6.6) \\
5(4.5)\end{array}$ & $\begin{array}{c}00 \\
1(4) \\
2(8) \\
1(4) \\
00\end{array}$ \\
\hline \multirow[t]{2}{*}{$\begin{array}{l}\text { Gram Negative } \\
\text { Organisms }\end{array}$} & $\begin{array}{l}10(11.1) \\
11(12.2)\end{array}$ & $\begin{array}{c}00 \\
2(8)\end{array}$ \\
\hline & $n=64$ & $n=6$ \\
\hline $\begin{array}{r}\text { Table 1: } S p \\
\text { isolated from }\end{array}$ & $\begin{array}{l}\text { trum of anaer } \\
\text { udy \& control }\end{array}$ & \\
\hline
\end{tabular}

\section{REFERENCES}

1. Mane K, Karamarkar AP, Bharadwaj RS. Anaerobic bacteria in subjects with chronic periodontitis and in periodontal health. J Oral Health Comm Dent 2009;3(3):49-51. 
2. C, Nonnenmacher R Mutters, L Flores de Jacoby. Microbiological characteristics of subgingival microbiota in adult periodontitis, localized juvenile periodontitis and rapidly progressive periodontitis subjects. Clin Microbiol Infect 2001;7:213-217.

3. Van Winkelhoff AJ, Loss BG, Van der Reijden WA, et al. Porphyromonas gingivalis, Bacteroides forsy thus and other periodontal pathogens in subjects with and without periodontal destruction.

J Clin Periodontol 2002;29:1023-1028.
4. Mohammad Hossein Salari, Zainab Kadkhoda. Rate of cultivable subgingival periodontopathogenic bacteria in chronic periodontitis. Journal of Oral Science 2004;46(3):157-161.

5. Catherine AS, Myrana TM, Marrisa MA, et al. Microbiologic and clinical profile of anaerobic diabetic foot infections. Phil J Microbiol Infect Dis 2002;31(4):151-160. 